\title{
The Florence Nightingale's nursing theoretical model: a transmission of knowledge
}

\author{
El modelo teórico enfermero de Florence Nightingale: \\ una transmisión de conocimientos \\ O modelo da Teoria Ambientalista de Florence Nightingale: \\ uma transmissão de conhecimento \\ Maria Angélica de Almeida Peres ${ }^{\mathrm{a}}$ \\ Pacita Geovana Gama de Sousa Aperibense ${ }^{b}$ \\ María de las Mercedes de Dios-Aguadoc \\ Sagrario Gómez-Cantarino ${ }^{d}$ \\ Paulo Joaquim Pina Queirós ${ }^{\mathrm{e}}$
}

\begin{abstract}
How to cite this article: Peres MAA, Aperibense PGGS, Dios-Aguado MM, Gómez-Cantarino S, Queirós PJP. The Florence Nightingale's nursing theoretical model: a transmission of knowledge. Rev Gaúcha Enferm. 2021;42(spe):e20200228. doi: https://doi.org/10.1590/19831447.2021.20200228
\end{abstract}

\footnotetext{
Universidade Federal do Rio de Janeiro (UFRJ), Escola de Enfermagem Anna Nery, Departamento de Enfermagem Fundamental. Rio de Janeiro, Rio de Janeiro, Brasil.

- Universidade Federal do Rio de Janeiro (UFRJ), Campus Macaé Professor Aloísio Teixeira. Macaé, Rio de Janeiro, Brasil.

c Universidad de Castilla-La Mancha. Enfermera en Salud Comunitaria. Estudio Asociado HISAG-EP. Ciudad Real, Espanha.

¿ Universidad de Castilla-La Mancha. Ciudad Real, Espanha.

¿Escola Superior de Enfermagem de Coimbra. Coimbra, Portugal.
}

\section{ABSTRACT}

Objective: To reflect on the contribution of Florence Nightingale in the health and nursing areas based on her epistemological legacy. Method: Reflection in which Florence Nightingale's nursing theoretical model is approached, trying to show how her family, training, social and cultural concepts influenced the formal construction of care.

Results: Florence Nightingale's vocation, profession and legacy stand out as faithful expressions of her thoughts for the professional constitution of the nurse. Responsible for the care of people with a strong humanitarian characteristic.

Conclusions: It is not possible to unravel nursing care today from Nightingale's thinking. This represents the power of a lifetime dedicated to the profession.

Keywords: History of nursing. Nursing theory. Biography. Nursing. Professional role.

\section{RESUMEN}

Objetivo: Reflexionar sobre la contribución de Florence Nightingale en el área de la salud y la enfermería a partir de su legado epistemológico.

Método: Reflexión en que se aborda el modelo teórico enfermero de Florence Nightingale, intentando poner de manifiesto cómo influyeron su familia, formación, conceptos sociales y culturales, en la construcción formal del cuidado.

Resultados: La vocación, profesión y legado de Florence Nightingale se destacan como expresiones fieles a sus pensamientos para la constitución profesional de la enfermera. Responsable del cuidado de las personas con una fuerte característica humanitaria.

Conclusiones: No es posible desentrañar el cuidado de enfermería hoy en día del pensamiento de Nightingale. Esto representa el poder de toda una vida dedicada a la profesión.

Palabras clave: Historia de la enfermería. Teoría de enfermería. Biografía. Enfermería. Rol profesional.

\section{RESUMO}

Objetivo: Refletir sobre a contribuição de Florence Nightingale na área da saúde e da enfermagem partindo do seu legado epistemológico.

Método: Reflexão baseada no modelo teórico de enfermagem de Florence Nightingale, procurando mostrar como seus conceitos de família, formação, social e cultural influenciaram a construção formal do cuidado.

Resultados: A vocação, a profissão e o legado de Florence Nightingale destacam-se como expressões fiéis de seus pensamentos para a constituição profissional da enfermeira. Responsável pelo cuidado de pessoas com forte característica humanitária.

Conclusões: Atualmente não é possível separar os cuidados de enfermagem do pensamento de Nightingale. Isso representa o poder de toda uma vida dedicada à profissão.

Palavras-chave: História da enfermagem. Teoria de enfermagem. Biografia. Enfermagem. Papel profissional. 


\section{口INTRODUCTION}

The life of Florence Nightingale (1820-1910) researched and told in many languages is itself of great interest. As far as we know, through her memories, her birthplace is known, from which she owes her name (Florence, Italy)(1). This woman grew up in England, in a wealthy family, deeply religious and with a high cultural level. Being the father figure essential for Nightingale, due to his reformist ideas and his fervent defense of the education of women. Facts that allowed her to be instructed in mathematics, religion, philosophy and to master several languages ${ }^{(1)}$. However, during the 19th century, women maintained a subordinate position in relation to men, both in the political, social, and cultural sphere. The female figure was relegated to the domestic sphere, an issue that ran into Nightingale's ideals. From a very young age (17 years old), she felt a vocation for teaching and caring for the other. When she was 23 years old, after communicating that she would be a nurse, her mother flatly refused, since this profession, at that time, was practiced by women of low class and without reputation ${ }^{(2)}$.

At this time, Nightingale knows the existence of religious orders belonging to the Catholic Church, which were in charge of social work with the poor. "In Protestantism, the creation of the ministry of deaconesses also arises from the possibility of women engaging in charitable social practice" ${ }^{\prime \prime 3: 243)}$. It is, therefore, that "this awareness of having" social duties "permeates the lady of the Protestant work of the 19th century" ${ }^{\prime \prime 2: 250)}$. Florence Nightingale is part of this Protestant feminist movement, where "the mission to save the world, deeply anchored in the evangelical tradition, takes for certain feminists, the form of a civilizing work" ${ }^{\prime \prime}(4560)$. It is in this British, Anglican context that "great female figures with international influence emerge, such as Josephine Butler, who deals with prostitutes, Elizabeth Fry, reformer of the prison condition, and Florence Nightingale, who organizes the nursing profession" ${ }^{\prime \prime}(3: 250)$.

During her travels, in his eagerness to learn the art of care, she systematized his notes, analyzed hospital reports, and reviewed official publications related to public health. Experiences that formed her in responsibility towards the others and reinforced her firm decision to serve the diseased ${ }^{(5)}$.

In 1853 the Crimean War broke out, where conditions in military hospitals were bleak. These places were run by English soldiers, and lacked any nursing service ${ }^{(1)}$. Therefore, it was was launched an expedition of 38 volunteer nurses, led and trained by Nightingale. This woman and her team, in just two weeks, organized the military hospital services. Nightingale researched and reviewed the data recorded during her night walks among the sick. Thus, she discovered that infectious diseases caused the death of soldiers admitted to the hospital, to a greater extent than the war wounds themselves. These women managed to enable a kitchen, providing adequate food to the sick. They even supplied fresh vegetables paid for with donations. They also set up a laundry, where patients' clothes were disinfected. In addition, they provided the soldiers with new shirts, which were bought with the salaries of the nurses themselves. The issuance of these sanitation companies achieved that the mortality rate of those admitted to the hospital fell from $40 \%$ to $2 \%(5)$.

Therefore, the Crimean War (1853-1856) can be said to have been the origin of contemporary nursing. To demonstrate her discovery, she began to explain it through statistics. She created the Rose Diagram, later known in mathematical language as the Polar Area Diagram. With this it was possible to demonstrate the importance of hygiene within health institutions ${ }^{(2)}$. Because of this, Nightingale can be considered a pioneer in the nursing discipline. Her ideas placed special emphasis on the basic sciences through mathematical knowledge. She used statistics to measure the impact of patient care. She also managed it for the correct sanitary design of hospitals and to reduce the deaths of admitted patients, even in times of peace ${ }^{(6)}$.

Nightingale wrote approximately 20,000 letters addressed to friends and acquaintances, expressing her ideas and discoveries. In addition, she wrote some 200 books, reports and brochures that had a profound impact on health and the reorganization of health services. Nightingale's writings can help to interpret your actions. Even when she was handicapped by her weakened health, she would meet at home carrying out an achievement of all her projects. She also helped to guide some of the great leaders in nursing, graduates of her school, providing support and guidance for their careers ${ }^{(5)}$.

When celebrating 200 years of the birth of Florence Nightingale and, when the World Health Organization (WHO) has declared 2020 the International Year of Nursing and Midwifery, it leads us to deep reflections about her model of care. This woman thought of nursing as a female profession, constructed and developed by nurses. Recognized by the medical category and society as different in the health field. It placed nurses as teachers and at the head of the nursing school management. In addition, they occupied places until then reserved exclusively for the medical corps. She ranked nursing care actions through the acquisition of competences. She promoted the regulated training of nurses at different socio-health levels, so that their vocation would take them to the place where they could best apply their nursing knowledge from a scientific base ${ }^{(7)}$. 
This article aims to reflect on the contribution of Florence Nightingale in the health area and nursing based on her epistemological legacy.

\section{METHODS}

Nursing is a science of health and human, where the center of attention, care and responsibility is man in all his dimensions. The diversity of models and theories of Nursing are a reflection of the evolution of the profession itself. Therefore, it is intended to reflect on the nature of care from the perspective of F. Nightingale. As well as endorse the importance of the epistemological development of the Nursing discipline, presenting the concepts of the metaparadigm according to its model of care. Which have generated nursing interventions that reinforce and balance the scientific, technological jointly with the human. Question that demonstrates the relationship of scientific theoretical knowledge in relation to the nursing professional practice. In this sense, Nightingale with her Environmental Theory, promotes and conserves the patient's vital energy. Taking into account the action that nature exerts on individuals, placing them in the best possible conditions to act on them ${ }^{(2)}$. Her influences were observation, education, and direct experience.

The Paradigm used by the author focuses on categorization, where the main center is the patient's own environment. Therefore, most of Nightingale's instructions about the professional practice of nursing are related to: 1 ) the analogy of the patient with his environment; 2 ) the nurse's correlation with the patient and 3) the nurse's relationship with the patient's environment (Figure 1).

Nightingale's theoretical scope is based on analysis, reasoning, and logical arguments to identify the phenomena and the epistemological concepts. According to the meaning of Nursing, this author is within a humanistic tendency which includes ideas based on respect and human dignity. It is concerned that the person reaches a comprehensive and multidimensional development, creating quality life conditions and well-being. Where trust and respect are present in the nurse-patient (family-community) relationship ${ }^{(8)}$.

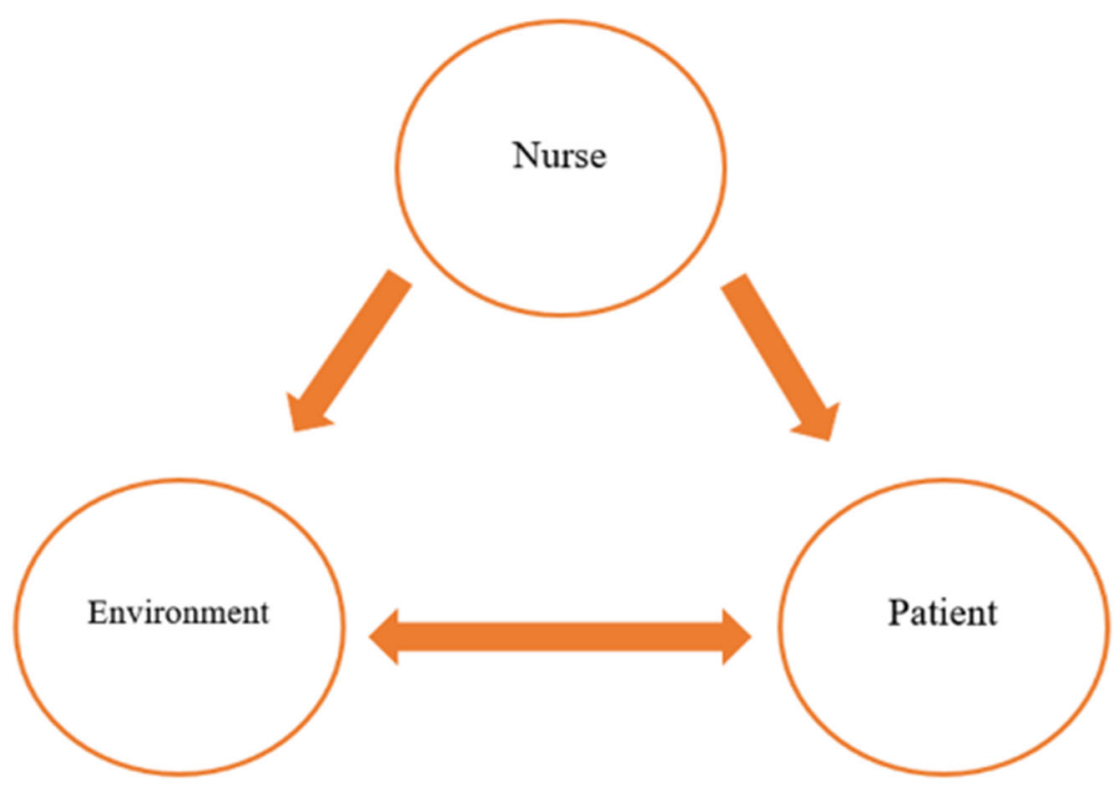

Figure 1 - Professional nursing practice as F. Nightingale's instructions

Source: Author's own creation

\section{METAPARADIGM}

The metaparadigm provides nursing with a unique panorama through its concepts that differentiate it from other disciplines. Nightingale describes the main metaparadigmatic concepts that refer to the person, environment, health and care, to carry out the performance of nursing as a discipline ${ }^{(2)}$. It is a systematic construction about the nature of nursing, its mission and care. It even describes the relationships between ideas and main values, giving rise to care actions from health practice at the hospital and home level. 
Thus the "person" acts as a passive subject, although supported the opinions of the patients in the decisions where they were involved. Nightingale sees the human being affected by the environment. Supported by taking into account the opinions of patients, in decisions where they are involved. It consists of a physical, emotional and intellectual component, without neglecting the spiritual(5,8).

Regarding the "environment" critical and key point for this theory, it facilitates the repair of the healthy and sick person, leading them to preserve and restore health. This term really takes into account social aspects, such as interpersonal relationships (which can cause health alterations), as well as emotional ones (music, poetry, among others). Without leaving aside the influence of physical aspects, to alter or not the health of people. It expresses the relationship of the person with the environment as a whole, taking into account the object's transformations and its development ${ }^{(2,8)}$.
While it is true that the concept of "health" is understood as the sensation of feeling good, as well as the ability to make the most of the person's faculties. Avoiding the appearance of the disease. Once this appears, it will be treated as a restorative process. Nightingale, attaches great importance to both observation and experience itself, which will be key to maintaining or losing people's health ${ }^{(2,8)}$.

In this sense, "nursing" falls on the female figure, who must be honest, virtuous and practice the profession with vocation and fidelity. In addition, it collaborates to provide a suitable environment, facilitating the recover of the person. Being the nurse totally loyal to the patient ${ }^{(9-10)}$ (Figure 2).

This theoretical approach assesses the need for a healthy environment, to apply adequate nursing care. In addition, her theory has significantly influenced other theories, such as the Theory of Adaptation, Theory of Needs, and the Philosophy of human caring.

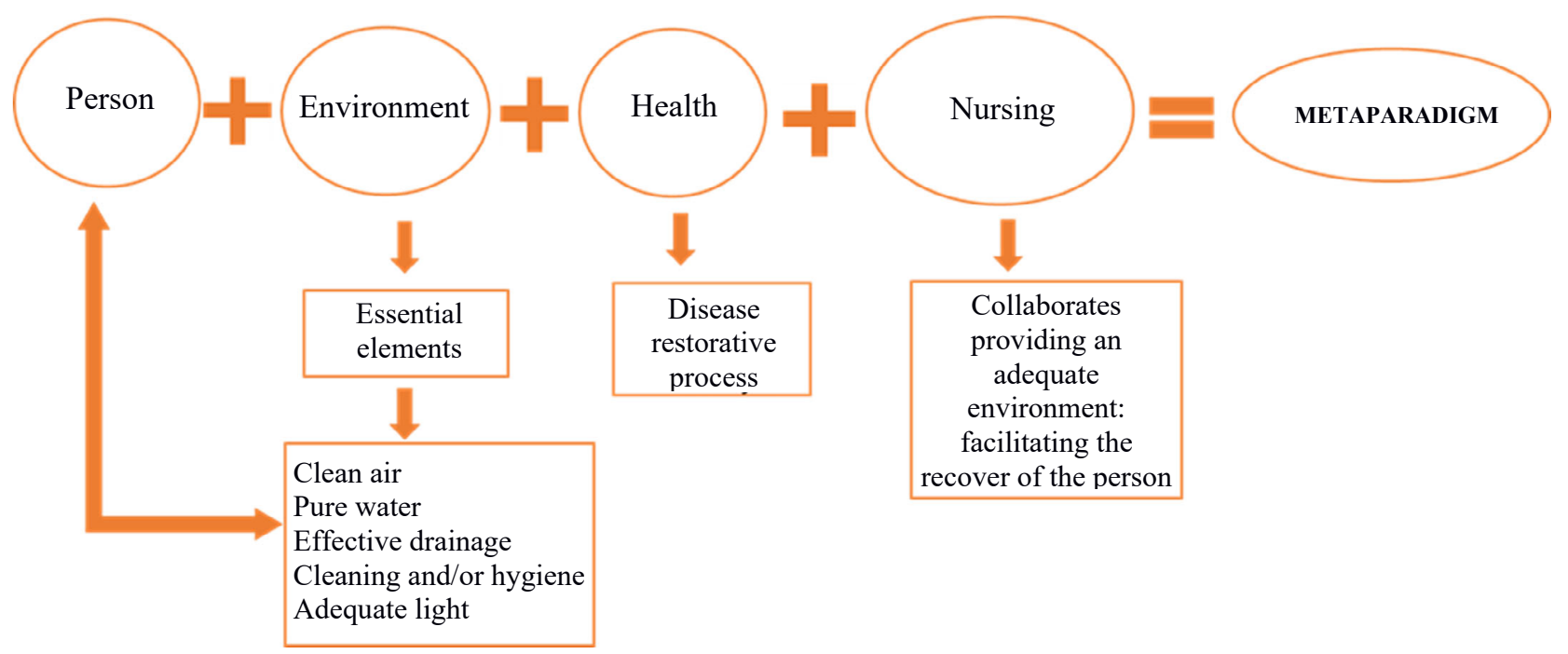

Figure 2 - Structure of the metaparadigm from Nightingale's view Source: Author's own creation.

\section{RESULTS AND DISCUSSIONS}

\section{The vocation}

Nightingale, faithful to what she considered a divine calling, devoted all her efforts to caring for the vulnerable. Fact that allowed an approach to the charitable sisters of the Vincentian congregation ${ }^{(7)}$. In addition, it made it easy to imagine that the religious reform that preceded the contemporary nursing period was fundamental to make way for nursing at home and hospitals. Both environments significant for the care, the promotion and the recovery of health ${ }^{(7,9)}$.

Therefore, her own desire to care for the patient with quality, helped to design, in the field of health sciences, the nursing profession ${ }^{(9)}$. Also this woman affirmed that the look of the person who cares for must observe the intangible aspects ${ }^{(10)}$. She commented that, through reflection, the caregiver knew how to care for the diseased. It indicated that, through practice, the nurses achieved the necessary skills to carry out quality nursing care ${ }^{(9-10)}$. 
The attention and care that Nightingale offered to the human being went beyond the wounds of the body. Well, she was equally concerned with emotional and psychic wounds ${ }^{(4)}$. Thus, she was in charge of writing letters to relatives of sick soldiers, since it was as important to alleviate the pain experienced by the wounded man, as it was to deal with the suffering of the families ${ }^{(6)}$. A matter that would have been poetically described by the soldiers he dealt with in Scútari, which earned her to be known as "The Lady with the Lamp"(11).

\section{The profession}

The origin of the so-called "Contemporary Nursing" dates back to 1860, when Florence Nightingale founded in London a school of female nursing within St. Thomas Hospital. This school was run by women, due to this, the beginnings were not easy due to the prevailing patriarchal culture of the time ${ }^{(5,8)}$. Her strong religious beliefs were reflected in a large part of her writings, being curious her ability to link science and religion. Thus, the symbolism of the Nightingale school is reminiscent of that required to embrace the novitiate within a Catholic religious congregation ${ }^{(5)}$. This fact has conditioned the association of the nurse for a period of time with highly feminized virtues related to compassion, self-denial, heroism and sacrifice ${ }^{(12)}$. While it is true that this profession applies the principles of the social and human sciences. Well, nursing is reaffirmed in its day to day, as a theoretical scientific field, and of the care ${ }^{(10)}$.

A question that in turn implies that the art of caring for people to restore their best health condition will be an act of conscience ${ }^{(8,11)}$. Therefore, the profession uses the art of care in its actions, without distinction of creed, social or cultural condition ${ }^{(8-9)}$. As Florence Nightingale defended in Scurati, recognizing in the cared person her processes of transformation or change, accompanying her with a humble and loving listening capacity ${ }^{(5)}$. Although it is true that nursing has a holistic character and studies the human being immersed in their culture, considering its specific characteristics ${ }^{(10)}$.

\section{The legacy}

In Brazil, the Nightingale model has exceeded what could be considered national nursing. Building a public health strong enough to require transformations in hygiene, promotion and prevention policies. The School of Nursing of the National Department of Public Health was the first responsible for the dissemination of the Nightingale bases in the country. By having its direction handed over to Brazilian nurses, the school soon reached out to its inspiring
Florence Nightingale, maintaining strong links between science and religion ${ }^{(11)}$.

Starting in the 1930s, Brazilian nursing was scientifically established in approximately 50 years ${ }^{(12)}$. Coinciding with the first doctorate course in nursing in the country as a milestone. This represents the strength of Brazilian nursing, its intellectual and work capacity, its political and social aptitude ${ }^{(13)}$.

Nightingale, an abolitionist woman and above all a humanist, was a precursor of freedoms for the female sex within a patriarchal society. In addition, she managed to value the nursing profession, until then considered a second-rate occupation. Well, nursing care was carried out by impoverished women with a low cultural level ${ }^{(10)}$. It is also possible to consider that she extended the concept of care and help to the needy. Through her writings on the Crimean War, she inspired Henri Dunant (1828-1901), founder of the International Red Cross movement. In fact, during the first conference of this entity held in 1863, the great work done by Nightingale in Scurati was praised. This recognition was made public during a conference held in London (1872), where Henri Dunant requested to regulate the conditions of prisoners of war: "This noble lady, by commendably assisting vulnerable people without distinction of social class and creed, was pioneer of a new universal charity, because although I am known as the founder of the Red Cross and creator of the Geneva Conventions, it was Nightingale who inspired my work"(14:61).

In this regard, it is worth mentioning the figure of Nicasio Landa (1830-1891), a Spanish military doctor, who promoted the founding of the Spanish Red Cross in 1864, being president of the male branch. He invented the "Landa apron", which served to transport the wounded from the battlefield to the point where they could be treated or ambulances approach. On the other hand, Concepción Arenal (1820-1893), an illustrated woman, jurist, writer, and above all humanist. She was the first female secretary of the Spanish Red Cross ${ }^{(4)}$. She devoted all her efforts, like Nightingale, to caring for the vulnerable by defending them from injustice. Both even shared their feminist ideas within a paternalistic society. Through her work "Beneficence, Philanthropy, and Charity" (1861), she denounced the lousy hygiene conditions in the country. Issue that allowed to encourage changes in public health. Arenal's efforts were rewarded when in 1918 the Queen Victoria Eugenia of Battenberg (1887-1969) founded the Red Cross School of Nurses based on the model established by Nightingale(14).

However, in Spain, the Saint Elizabeth of Hungary School of Nursing, founded in 1896, already followed the Nightingale model. Its founder Federico Rubio y Gali (1827-1902), shared thoughts and teachings with this woman, during her stay 
as Ambassador in London. An advocate for the importance of social medicine and hygiene, where handwashing, as he learned from Nightingale, meant controlling infections and improving the quality of care for people $e^{(15)}$.

In this regard, point out the interest of both to achieve a nursing trained in the direction and management of responsibilities, assuming risks to achieve the healing of the sufferer. Therefore, it is verified that nursing training in a regulated manner, based on the social and human sciences, entails achieving professionals with academic knowledge to develop management, teaching, research and professional practice functions ${ }^{(15)}$.

It is possible to affirm that Florence Nightingale is the creator of modern nursing. Highlight her role as an administrator, educator, and statistician, who dedicated her life to caring for human life in an organized, practical, and scientific way. Woman present in every member of the nursing today.

\section{FINAL CONSIDERATIONS}

The Nightingale School opened the doors of a path forward for women in the 19th century, through the professionalization of science-based nursing. She advocated for the training of women, capable of uniting around a profession to transform society and promote health.

Her dedication to evidence gathering and respectability came with a desire to combat suffering and inequality. For Nightingale, the concept of compassion had the sense of human quality, the mystique of spirituality, which should guide nursing care.

Evoke in the year 2020, the collective memory of F. Nightingale represents good work and courage for nursing, through a scientific and regulated training. Because it is allowing nursing to demonstrate against COVID-19 (Coronavirus Disease 2019), its technical-assistance preparation, emerging, even more, its human base. Nightingale considered that the sanitation of the population was healthy. It demonstrated the need for ventilation, light, nutritious food, and exercise to restore health. In hospitals, she believed that beds should be at a distance and that nurses should wash their hands regularly. Measures are currently being strengthened at the political-assistance level due to the pandemic situation. Therefore, the poetry that involves the cognomen of the "Lady with the Lamp" received by Nightingale will serve here, to approach the contributions left to society, regarding the care of patients from a formal and human perspective, in Nightingale's perception and construction.

Nursing care today cannot be unraveled from Nightingale's thinking. This represents the power of a lifetime, dedicated to formalizing a profession with a scientific basis. The actions to face the disease caused by COVID-19 are showing the changes that have occurred in the organization and operation of health teams, and the value of nursing within them. Generating the creation of multidisciplinary health teams, which share care competencies for the person to be cared for.

When it is two hundred years since the birth of this illustrious writer, mathematician, nurse and above all humanist, we discover that her thoughts reach the category of timeless, because after two centuries, it can still be verified that they are totally current and updated.

Florence Nightingale, as a woman and a thinker, provided to society, based on her vocation and social purpose, her thinking regarding the health sciences, which crystallized into a scientifically based profession, leaving an epistemological legacy for the care of the human being. To educate society, and to practice nursing critically, keeping up-to-date and innovating within their professional field.

\section{REFERENCES}

1. Rakoczy S. Florence Nightingale: discernment as trusting. HTS Teolog Stud. 2018 Sep;74(3):a5043. doi: https://doi.org/10.4102/hts.v74i3.5043

2. Taquechel ML, Díaz JA, Figueroa MAR, Mora MA. Eticidad del pensamiento de Florence Nightingale. Rev Haban Cienc Méd. 2013 Dec [cited 2020 Jun 02];12(4):688-96. Available from: http://scielo.sld.cu/scielo. php?script=sci_arttext\&pid=\$1729-519X2013000400021\&lng=es

3. Baubérot J. Da mulher protestante. IN: Duby G, Perrot M, organizadores. História das mulheres no ocidente: o século XIX. Porto: Afrontamento; 1991. v. IV, p. 239-55.

4. Kappeli A-M. Cenas feministas. In: Duby G, Perrot M, organizadores. História das mulheres no Ocidente: o século XIX. Porto: Afrontamento; 1994. p. 540-79.

5. Young P, Smith VH, Chambi MC, Finn BC. Florence Nightingale (1820-1910): 101 years after her death. Rev Med Chil. 2011 Jun;139(6):807-13. doi: http:// doi.org/10.4067/S0034-98872011000600017

6. Kopf EW. Florence Nightingale as statistician. . Public Am Stat Assoc. 1916 [cited 2020 Jun 02];15(116):388-404. Available from: https://amstat.tandfonline.com/ doi/pdf/10.1080/15225445.1916.10503703?needAccess=true\#.XtbqvipKg2w

7. Martínez EMB. Una extraordinaria mujer en la más noble profesión "Florence Nightingale". Rev Salud Cienc. 2017 Nov [cited 2020 Jun 02];1(1):19-23. Available from: https://revistas.utb.edu.ec/index.php/saludyciencias/article/view/328

8. Medeiros ABA, Enders BC, Lira ALBC. The Florence Nightingale's environmental theory: a critical analysis. Esc Anna Nery. 2015;19(3):518-24. doi: https://doi. org/10.5935/1414-8145.20150069

9. Rafferty AM. Nurses as change agents for a better future in health care: the politics of drift and dilution. Health Econ Policy Law. 2018 Jul;13(3-4):475-91. doi: https://doi.org/10.1017/S1744133117000482

10. Magpantay-Monroe ER. Exploring the emotional intelligence of Florence Nightingale. Asia Pac J Oncol Nurs. 2015 Apr-Jun;2(2):107-11. doi: https://doi. org/10.4103/2347-5625.157587

11. Barreira IA. A reconfiguração da prática da enfermagem brasileira em meados do século 20. Texto Contexto Enferm. 2005;14(4):480-7. doi: https://doi. org/10.1590/50104-07072005000400003 
12. Machado MH, Oliveira ES, Lemos WR, Wermelinger MW, Vieira M, Santos MR, et al. Perfil da enfermagem no Brasil: relatório final. Rio de Janeiro: NERHUS DAPS - ENSP/Fiocruz. 2017 [citado 2020 Jun 02]. v. 1. Available from: http:// www.cofen.gov.br/perfilenfermagem/pdfs/relatoriofinal.pdf

13. Mendes ALTM, Aperibense PGGS, Almeida Filho AJ, Peres MAA. Nursing master's program at Anna Nery School 1972-1975: singularities of graduating and challenges in its implementation. Esc Anna Nery. 2015 Mar;19(1):11-7. doi: https://doi.org/10.5935/1414-8145.20150002

\section{- Authorship contribution:}

Conceptualization: María de las Mercedes de DiosAguado e Maria Angélica de Almeida Peres.

Methodology: Maria Angélica de Almeida Peres, María de las Mercedes de Dios-Aguado e Sagrario Gómez-Cantarino.

Supervision: Maria Angélica de Almeida Peres.

Visualization: María de las Mercedes de Dios-Aguado e Sagrario Gómez-Cantarino.

Writing-original draft: Maria Angélica de Almeida Peres e Pacita Geovana Gama de Sousa Aperibense.

Writing-review \& editing: Maria Angélica de Almeida Peres, Pacita Geovana Gama de Sousa Aperibense, María de las Mercedes de Dios-Aguado e Sagrario GómezCantarino e Paulo Joaquim Pina Queirós.

\section{- Corresponding author:}

Pacita Geovana Gama de Sousa Aperibense

Email: pacitageovana@yahoo.com.br
14. Dowdeswell TL. The Brussels Peace Conference of 1874 and the modern laws of belligerent qualification. Osgoode Hall Law J. 2017 [cited 2020 Jun 03];54(3):805-50. Available from: https://digitalcommons.osgoode.yorku.ca/ cgi/viewcontent.cgi?article $=3159 \&$ context $=0 h l j$

15. Borredá ES, Gabandé FF, Puig RC, Sarturi F. Florence Nightingale y Federico Rubio: reformadores de la Enfermería moderna española. Cult Cuid. 2012 May-Ago [cited 2020 June 02];16(33):43-9. Available from: https://rua.ua.es/ dspace/bitstream/10045/24151/1/CC_33_06.pdf

\section{Associate editor:}

Dagmar Elaine Kaiser

\section{Editor-in-chief:}

Received: 06.11.2020

Maria da Graça Oliveira Crossetti 